\title{
Revista Brasileira de Fruticultura \\ Water potential in peach branches as a function of soil water storage and evaporative demand of the atmosphere ${ }^{1}$
}

\author{
Alex Becker Monteiro², Carlos Reisser Júnior ${ }^{3}$, Luciano Recart Romano ${ }^{4}$, \\ Luís Carlos Timm ${ }^{5}$, Marcos Toebe ${ }^{6}$
}

\begin{abstract}
The use of water potential indicators in the plant has been adopted in irrigation management, in recent years, since it is accepted that the plant is the best indicator of its own water status. The objective of this study was to verify the relationship between water potential in peach tree branches and the evaporative demand of the atmosphere and the water availability in two textural classes of an Aquertic Hapludalf soil, aiming to adopt irrigation management strategies based on the water potential in the plant. Research was carried out in a commercial peach orchard, cv. Esmeralda, in the municipality of Morro Redondo-Rio Grande do Sul state, Brazil. Four peach tree rows were evaluated, being two irrigated and two non irrigated. The irrigation management was based on the replacement of the potential crop evapotranspiration. It was concluded that the water potential in the peach tree branch is positively related with the evaporative demand of the atmosphere and negatively related with soil water storage. Future studies should adopt irrigation management strategies for peach trees based on the water potential mainly for the irrigation management of post-harvest peach trees.

Index terms: Prunus persica (L.), water status, evapotranspiration, soil water content, irrigation management.

\section{Potencial de água no ramo de pessegueiro em função do armazenamento de água no solo e da demanda evaporativa da atmosfera}

Corresponding author:

E-mail: alexbeckermonteiro@gmail.com

Received: September 19, 2016.

Accepted: April 03, 2017.

Copyright: All the contents of this journal, except where otherwise noted, is licensed under a Creative Commons Attribution License.

\section{(cc) $\mathrm{EY}$}

Resumo-A utilização de indicadores do potencial de água na planta tem sido adotada no manejo da irrigação ao longo dos últimos anos, pois é admitido que a planta seja o melhor indicador de seu próprio estado hídrico. O objetivo do presente trabalho foi verificar a relação do potencial da água nos ramos do pessegueiro com a demanda evaporativa da atmosfera e com a disponibilidade de água em duas classes texturais de um Argissolo Bruno-Acinzentado, visando à adoção de estratégias de manejo da irrigação em pessegueiros, baseada no potencial de água na planta, em um pomar comercial de pessegueiro, cv. Esmeralda, no município de Morro Redondo-Rio Grande do Sul Foram avaliadas plantas em quatro linhas de pessegueiro, sendo duas irrigadas e duas não irrigadas. O manejo da irrigação foi baseado na reposição da evapotranspiração potencial da cultura. Concluiu-se que o potencial de água no ramo do pessegueiro apresenta uma relação direta com a demanda evaporativa até o final da colheita dos frutos e uma relação inversa com o armazenamento de água no solo. Futuros estudos devem ser realizados, baseados no manejo da irrigação por meio do potencial de água na planta de pessegueiro principalmente, na pós-colheita. Termos para indexação: Prunus persica (L.), estado hídrico, evapotranspiração, conteúdo de água no solo, manejo da irrigação. 


\section{Introduction}

The fruit industry in Brazil, has been one of the agricultural activities that has booming the country's economic scenario in recent years, due to its high profitability in small areas, playing an important role in generating income and employment in the rural area mainly in small properties.

Temperate fruits have relevant socioeconomic importance in several regions of Brazil, especially in the states of Rio Grande do Sul, Santa Catarina, Paraná, São Paulo, Minas Gerais, either for fresh consumption, processing industries or agrotourism (FACHINELLO et al., 2011).

In Rio Grande do Sul (RS), the peach growing activity is increasing, with new areas being incorporated, as an economic and social alternative for counties that historically had no tradition in the peach tree cultivation (MADAIL, 2014).

Currently in the State, about 129 thousand tons are harvested in 12,582 hectares, with an average yield of 10.3 tons (IBGE, 2017), being Pelotas-RS and Canguçu-RS the municipalities with the largest cultivated areas, 3,000 ha and 2,600 ha, respectively. However, the average yields of $7 \mathrm{Mg} \mathrm{ha}^{-1}$, are below the average yield recorded for state and other municipalities, such as Bento Gonçalves-RS, which produces, on average, $15 \mathrm{Mg} \mathrm{ha}^{-1}$ (MADAIL, 2014).

In this context, several aspects related to the orchard production system still deserve attention, especially the possible need for irrigation as well as the response to water excess or deficit, during the peach cycle.

The use of water potential indicators in the plant has been adopted in irrigation management during the last years, since it is accepted that the plant is the best indicator of its own water status (CONEJERO et al., 2011). There are some methods that indicate the water status of plants, which serve as a reference for the irrigation management, such as: water potential of the branch (ABRISQUETA et al., 2012; ABRISQUETA et al., 2015; WELLS, 2015; HOCHBERG et al., 2016; MARSAL et al., 2016; MIRÁSAVALOS et al., 2016), stomatal resistance (TORRESRUIZ et al., 2013; ESMAEILPOUR et al., 2016), temperature of the vegetative canopy (GONZALEZDUGO et al., 2012; ZARCO-TEJADA et al., 2012), trunk diameter fluctuation (CONESA et al., 2016; DE LA ROSA et al., 2016) and turgor pressure monitoring (ZIMMERMANN et al., 2010; EHRENBERGER et al., 2012; RODRIGUEZ-DOMINGUEZ et al., 2012; BRAMLEY et al., 2013).

The water potential in the branch determines how efficiently the water is transported by the plant, since integrates the effects of soil, plant and atmospheric conditions on the water availability within the plant (WELLS, 2015). Abrisqueta et al. (2012) used the water potential in the branch for irrigation management and concluded that this is a fast, sensitive and effective tool for integrating the soil-plant-atmosphere system. This method can be an indication of the water stress level in the plant, characterizing the beginning and end of this period, and may be useful in the adoption of irrigation strategies, including inadequate irrigation.

Several authors have monitored the water potential in the branch at dawn (MARCHAND et al., 2013, MEDRANO et al., 2015, CHASTAIN et al., 2016). However, in the works of McCUTCHAN; SHACKEL (1992), ABRISQUETA et al. (2012, 2015), WELLS (2015), MARSAL et al. (2016) and MIRÁS-AVALOS et al. (2016), the water potential in the branch was monitored at noon since, according to these authors, it is when the plant expresses the greatest photosynthetic and water demand. Thus, measuring the water potential in the branch at noon detects the progressive development of water deficits in non-irrigated plants, as well as water potential levels in the branch, ideal for the good development of plants (McCUTCHAN; SHACKEL, 1992).

The objective of this work was to verify the relationship between water potential in the peach tree branches and the evaporative demand of the atmosphere and the soil water availability in two textural classes of an Aquertic Hapludalf soil aiming the adoption of irrigation management strategies in peach orchards based on the water potential of the plant.

\section{Material and methods}

The study was carried out from October to December 2014 in an a commercial peach orchard in Morro Redondo-RS, $-31^{\circ} 31^{\prime}$ '55.30' $\mathrm{S}$ and $52^{\circ} 35^{\circ}$ ' 37.87 "W and $243 \mathrm{~m}$ a.s.1. The climate of the region is Cfa type, according to Köppen classification, being temperate humid with hot summers. The region has annual mean temperature of $18^{\circ} \mathrm{C}$ and the average precipitation is $1,509.2 \mathrm{~mm}$. The annual mean of relative air humidity is $78.8 \%$ (TERRA, 2012). The soil was classified according to Santos et al. (2006), as Aquertic Hapludalf.

The peach orchard, of Esmeralda cultivar was planted in an area of 1.8 ha, consisting of 18 peach rows with trees spaced by $1.5 \mathrm{~m}$ along the row and $6.0 \mathrm{~m}$ between rows, totalizing 1,450 plants. The plants were harvested in four times, once a week.

By applying the Regionalized Variables Theory (Geostatistics), elaborated by Terra (2012), spatial distribution maps of the soil textural fractions in the orchard (sand, silt, and clay contents) and homogeneous areas were delimited. Two homogeneous areas were delimited having as predominant textural classes the Sandy Loam and Sandy Clay Loam.

The influence of soil water availability in each textural class on the water potential in the peach tree was evaluated in four rows of plants, two irrigated by drip irrigation and two not irrigated, separated by three rows, one from the other. The irrigation management in the 
experimental area was based on crop evapotranspiration, with water replenishment twice a week, on Mondays and Thursdays. Reference evapotranspiration data were obtained through an automatic meteorological station (EMA), installed near the peach orchard. The crop coefficient used was 1.0 based on the average values of the peach crop coefficient (ranging from 0.85 to 1.15 ) the same used by Allen et al. (1998).

A "Scholander" pressure chamber (SCHOLANDER; HAMMEL, 1965), branded "PMS Instrument Company", was used to monitor water potential in the branch. In each soil textural class combined with and without irrigation, one plant was selected in which two water potential readings were performed on two leaves of the middle part of the canopy. This leaves were previously covered with waterproof bags to prevent transpiration. Readings were performed twice a week (Mondays and Thursdays) between 11:00 a.m. and 1:00 p.m. The average value of the two readings was considered as the water potential in the branch.

The soil water content was monitored with a Diviner $2000^{\circledR}$ capacitance probe. Measurements were also performed twice a week, on Mondays and Thursdays, at depths of $0.10,0.20$ and $0.30 \mathrm{~m}$. A calibration equation for the capacitance probe was adjusted for each textural class. For the Sandy Loam textural class, the following equation was adjusted (MONTEIRO et al., 2015):

$$
\theta v=0.4700 \cdot \mathrm{FR}^{\wedge 3.3130} \quad \text { eq } 01
$$

where $\theta v$ is the volumetric soil water content estimated by the capacitance probe $\left(\mathrm{cm}^{3} \cdot \mathrm{cm}^{-3}\right)$ and FR is the relative frequency value. For the Sandy Clay Loam textural class, the following equation was adjusted (MONTEIRO et al., 2015):

$$
\theta v=0.4169 . \mathrm{FR}^{2.4268}
$$

The experimental design was completely randomized. Soil water content data were submitted to variance analysis as a $2 \times 2$ factorial: two irrigation levels (with and without irrigation) and two soil textural class (Sandy Loam and Sandy Clay Loam). When have interaction, the means were compared by Tuckey test as $5 \%$ of probability. Statistical analyses were performed with the help of the GENES software (CRUZ, 2013) and Office Excel ${ }^{\circledR}$ software.

\section{Results and Discussion}

The measured soil water content values $(\theta)$ in the 0-0.30 m layer were higher in the Sandy Clay Loam class without irrigation (Figure 1D), when compared to those observed in the Sandy Loam class without irrigation as well (Figure 1B). This is related to the water retention capacity of these two texture classes, being higher in the Sandy Clay Loam textural class. This higher water retention capacity did not reflect in lower $\Psi_{\mathrm{w}}$ values in the Sandy Clay Loam textural class (Figure 1D) when compared to $\Psi_{\mathrm{W}}$ values in the Sandy Loam textural class (Figure 1B). During the monitoring period, the pluviometric volume was $160 \mathrm{~mm}$ and the irrigation depth was $110 \mathrm{~mm}$ (Figure 1).

Water supplementation by irrigation maintained the water potential in the branch $\left(\Psi_{\mathrm{w}}\right)$ around -12 bar (-1.2 $\mathrm{MPa}$ ) for plant cultivated in the Sandy Loam textural class with irrigation throughout the studied period (Figure 1A), which is lower than that indicated by Abrisqueta et al. $(2012,2015)$, who mentioned that $\Psi_{\mathrm{w}}$ values approximately of -10 bar may correspond to an indication of high water stress. According to the classification proposed by Fulton et al. (2007), $\Psi \mathrm{w}$ value of -12 bar is classified as mild stress for the month of December and as mild to moderate stress for the month of August (in Northern hemisphere, this corresponding to June and February, respectively in the South). According to the authors, this value is below the level considered moderate and acceptable for the month of September (March in Southern hemisphere) (from -14 to -18 bar, respectively), that is, plants are not in water stress.

For irrigated plant, evaluated in the Sandy Clay Loam soil class (Figure 1C), it was observed that the ETP replacement through irrigation was not sufficient to maintain $\Psi_{\mathrm{w}}$ value around -12 bar as observed for the Sandy Loam soil class, with irrigation (Figure 1A). Abrisqueta et al. (2015) evaluated five irrigation management treatments, in Spain, during five years (2009/2013) and verified that 100\% ETP replacement was sufficient to maintain $\Psi_{w}$ between -2 and -9 bar, keeping $\Psi_{\mathrm{w}}$ values below those found in this study. The authors also obtained $\Psi_{\mathrm{w}}$ values from -4 to -12 bar in the irrigation treatment with $50 \%$ ETP replacement, values found in this work with the $100 \%$ ETP replacement.

The values among irrigated plants cultivated in the Sandy Clay Loam varied from -8 bar to -18 bar (Figure $1 \mathrm{C})$, whereas in the non irrigated ones it varied from -6 bar to -20 bar (Figure 1D). Although values were similar in terms of magnitude, the $\Psi_{\mathrm{w}}$ values had lower fluctuation in irrigated plants (Figure 1C), indicating that irrigation contributed to a lower variability in the $\Psi_{\mathrm{w}}$ values. It was also observed that the variation in the $\Psi_{\mathrm{w}}$ values in the branch during the monitored period, was lower in the irrigated Sandy Loam soil class (Figure 1A) when compared to the variation in the $\Psi_{\mathrm{w}}$ values in the irrigated Sandy Clay Loam (Figure 1C). This fact may be an indication that the replacement of the evapotranspiration rates of the peach tree grown in Sandy Clay Loam soils by irrigation may not be the best criteria for irrigation management. 


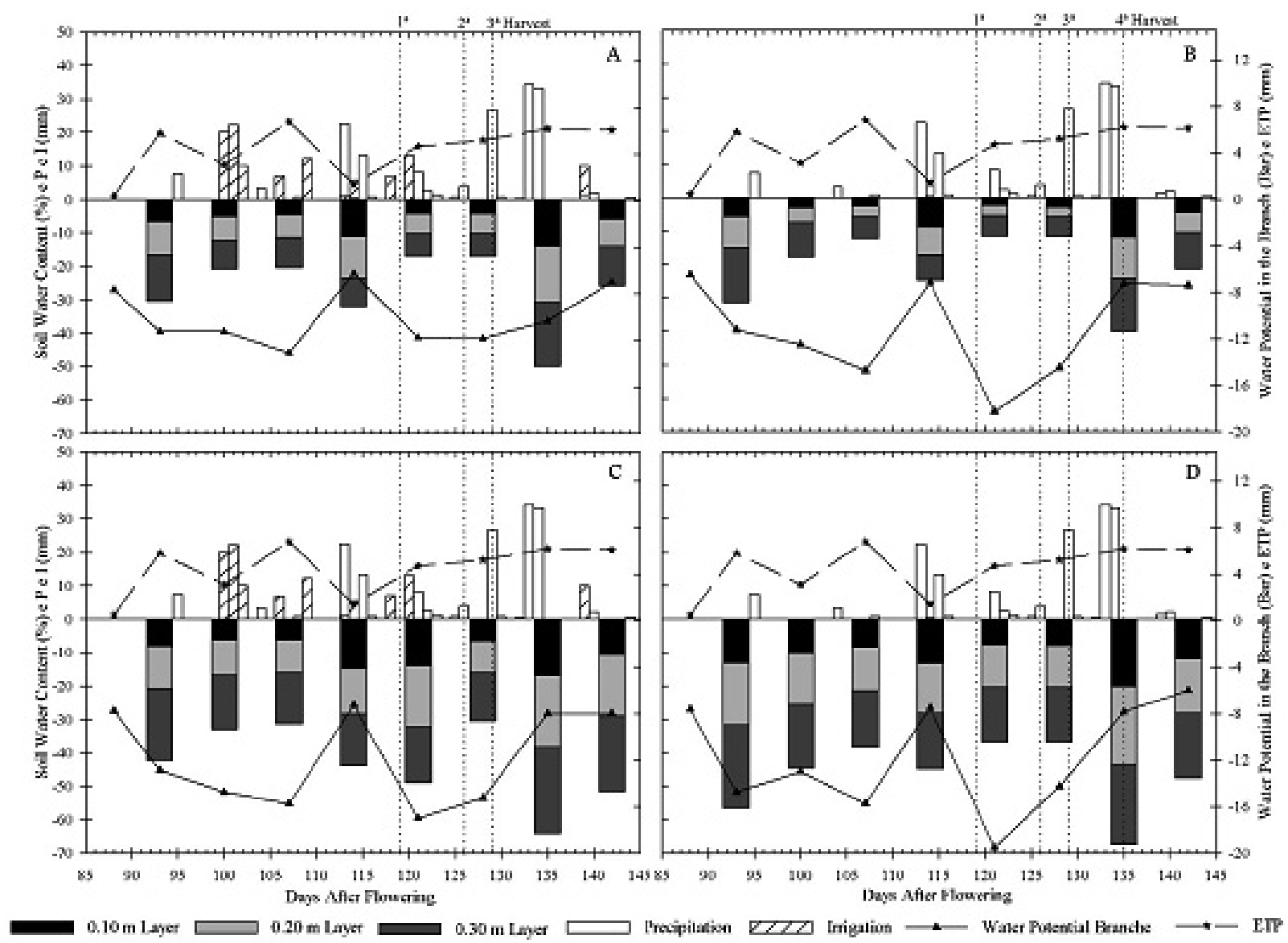

Figure 1. Temporal variation of the water potential in the branch $(\Psi \mathrm{w})$, precipitation $(\mathrm{P})$, irrigation depth $(\mathrm{I})$, potential evapotranspiration (ETP) and soil water content $(\theta)$ at $0.10 \mathrm{~m}, 0.20 \mathrm{~m}$ and $0.30 \mathrm{~m}$ for the period from 90 to 143 days after flowering (DAF) of irrigated peach. Morro Redondo - RS, 2014. (A - Sandy Loam textural class with irrigation, B - Sandy Loam textural class without irrigation, C - Sandy Clay Loam textural class with irrigation, D - Sandy Clay Loam textural class without irrigation).

Hochberg et al. (2017) reported that soil water replenishment, via irrigation, is more adequate based on crop evapotranspiration rates. However, in the present study it was observed that ETP replacement is not enough to keep the plants in a suitable water status.

During the observed period, the potential evapotranspiration variable, as an integral of the atmospheric evaporative demand, was positively related to the $\Psi_{\mathrm{w}}$ values, that is, lower $\Psi_{\mathrm{w}}$ values correspond to lower ETP values (Figure 2), and this positive relationship was observed until second week peach harvest (121 DAF). This fact may be related to the high water requirement of the plant during the phenological phase of fast fruit growth. At the end of this phase, a significant decrease in the physiological stress suffered by the plant until the last harvest was observed. Precipitation at 133 and $134 \mathrm{DAF}$ may also have influence in the reduction of water stress due to the changes in the plant's water demand, after the stressful period of water supply to the fruits.

High water demands determine that water supply by roots is not enough to overcome transpiration, which reduces the water potential in plant tissues. Hochberg et al. (2017) studying controlled deficits in vines also observed that high evapotranspiration results in a lower $\Psi_{\mathrm{w}}$ values along with a low stomatal conductance, demonstrating the high influence of evapotranspiration on the $\Psi_{\mathrm{w}}$ behavior.

The relationship between $\Psi_{\mathrm{w}}$ and evapotranspiration is nonlinear (Figure 2), represented by an exponential model with determination coefficient $\mathrm{R}^{2}=0.70$. This result corroborates the ones found by Itier et al. (1992), who stated that $\mathrm{ET}_{0}$ has a good relationship with the base matric potential, which is the water potential in the tissue of plants measured before sunrise. However, the authors reported that this correlation seems to be dependent on the soil characteristics and stage of crop development. Simões (2007) verified that the water potential in the peach tree measured at noon, is related to the substrate matric potential. However, this author observed that the water potential in the plant suffers interference from other factors, in addition to the water potential in the substrate, and this interference may be related to environmental factors such as wind and radiation. 


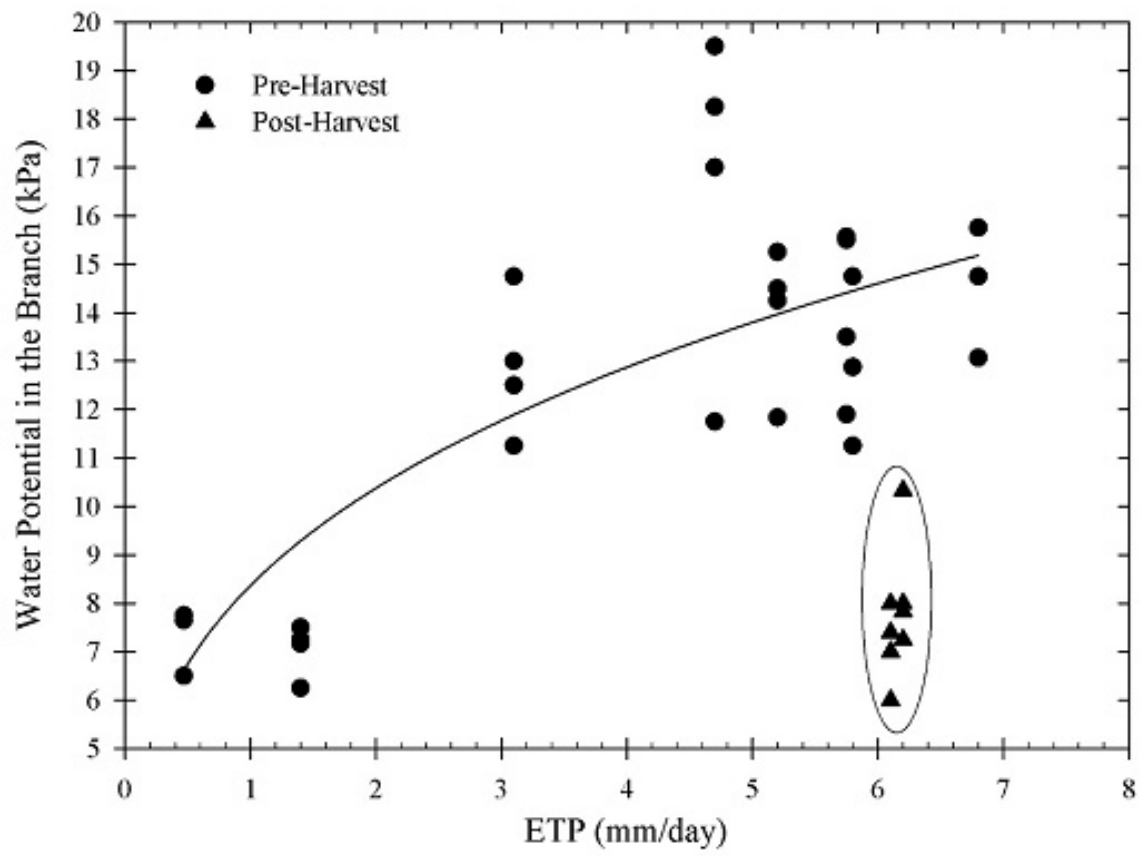

Figure 2. Water potential in the branch as a function of the potential evapotranspiration (ETP) in peach orchard regardless of textural class, with and without irrigation, including the pre-harvest and post-harvest phases. Morro Redondo - RS, 2014. [( $\left.\left.\Psi_{\mathrm{W}}=1.63 *\left(1-\mathrm{e}^{(-0.47 * \mathrm{ETP})}\right) ; \mathrm{R}^{2}=0.70\right)\right]$.

The $\Psi_{\mathrm{w}}$ values in the post-harvest period may be related to a possible reduction of plant stress since the fruits harvested (Figure 2). This post term may be related to the decrease in the water demand that plants needed to keep their fruits turgid and at high growth rate. Valancogne et al. (1996) also verified that $\Psi_{\mathrm{w}}$ is closely related to ETP, in several fruit crops. Itier et al. (1992) also found that $\Psi_{\mathrm{W}}$ is closely related to ETP in several annual crops.

In both textural soil classes, an exponential type equation was adjusted, with $\mathrm{R}^{2}$ value of 0.34 and 0.45 for Sandy Clay Loam and Sandy Loam, respectively, i.e., $\Psi_{\mathrm{W}}$ values correlated better with soil water storage in the Sandy Loam textural class (Figure 3).

The $\Psi_{\mathrm{w}}$ values in the Sandy Loam texture reached levels of approximately -15 bar, for soil water storage of approximately $12 \mathrm{~mm}$, while for the same $\Psi \mathrm{w}$ values in the Sandy Clay Loam, soil water storage was, approximately, $35 \mathrm{~mm}$. Bergonci et al. (2000) emphasized that it is important to consider the resistance involved in the process of soil water transfer to the root system of the crop. In addition to management, the soil particle size and mineralogical composition also influence the water retention, since the adsorption forces basically depend on the water depth that covers soil particles, which varies according to its specific surface. Thus, although water retention is expected to be higher in clayey soils (SILVA et al., 2005), the retained water may not be readily available to plants, even under conditions of high soil water storage values.
The largest soil water storage in the $0-0.30 \mathrm{~m}$ layer was observed in the Sandy Clay Loam soil class as compared to the same layer in the Sandy Loam (Figure 3). However, this higher water storage in the Sandy Clay Loam did not reflect higher water availability to plants, which can be observed through $\Psi_{\mathrm{w}}$ values (Figure 3). On a study to verify what would be the best water stress indicator for the peach tree, Remorini and Massai (2003) concluded that it is not always easy to relate the soil water content to the water status of plants.

Evaluating five irrigation treatments, Abrisqueta et al. (2015) concluded that soil water content is the main contributor to $\Psi \mathrm{w}$ values and emphasizes that it includes the soil-plant-atmosphere system, which was not observed in the present study where, the main contributor to $\Psi_{\mathrm{W}}$ values was ETP, until the end of the peach harvest. However, it was observed that after the peach harvest, the main contributor to $\Psi \mathrm{w}$ values was the soil water content.

Table 1 shows that there was a significant interaction between mean soil water contents in layers of 0.0-0.10 and $0.10-0.20 \mathrm{~m}$ depth for the evaluated factors (textural class and irrigation), whereas for layer of $0.20-0.30 \mathrm{~m}$ depth, there was only main effect of the soil textural class. The highest soil water content in the Sandy Clay Loam textural class was observed in both layers. 


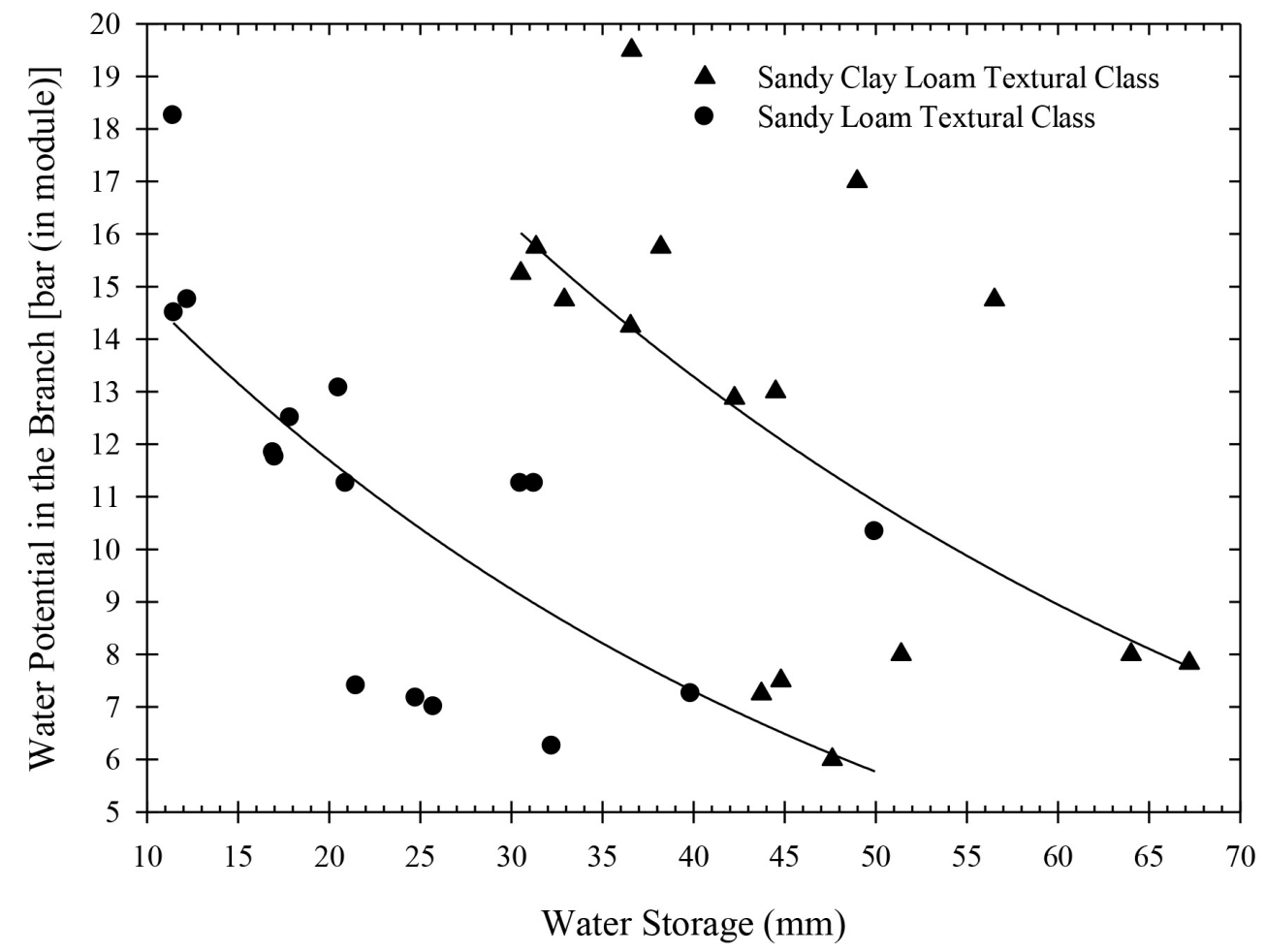

Figure 3. Water potential in the peach tree branch as a function of soil water storage, layer $0-0.30 \mathrm{~m}$ depth in each evaluated textural class, regardless of irrigation. Morro Redondo, Rio Grande do Sul, Brazil, 2014. Sandy Clay Loam Textural Class $\left(\Psi_{\mathrm{W}}=8.88^{*} \mathrm{e}^{\left(-0.02^{*} \mathrm{~A}\right)}-5.95^{*} \mathrm{e}^{\left(-0.02^{*} \mathrm{~A}\right)} ; \mathrm{R}^{2}=0.34\right)$. Sandy Loam textural class $\left(\Psi_{\mathrm{W}}=5.27 * \mathrm{e}^{\left(-0.024^{*} \mathrm{~A}\right)}-3.4^{*} \mathrm{e}^{(-}\right.$ $\left.{ }^{0.024 * A)} ; \mathrm{R}^{2}=0.45\right)$.

Table 1. Comparison between averages of soil water content $\left(\mathrm{cm}^{3} \mathrm{~cm}^{-3}\right)$ in layers of $0.0-0.10 \mathrm{~m}, 0.10-0.20 \mathrm{~m}$ and 0.20-0.30 m depth in Sandy Loam and Sandy Clay Loam classes with and without irrigation, evaluated in a peach experiment in the 2014 harvest by the Tukey test at $5 \%$ probability.

\begin{tabular}{|c|c|c|c|}
\hline Textural Class / Irrigation Factor & With irrigation & Without irrigation & $\begin{array}{c}\text { Main Effects of Soil } \\
\text { Textural Classes }\end{array}$ \\
\hline \multicolumn{4}{|c|}{ - } \\
\hline Sandy Loam & $0,0505 \mathrm{~B}$ & $0,0701 \mathrm{~B}$ & 0,0603 \\
\hline Sandy Clay Loam & $0,1147 \mathrm{~A}$ & $0,1033 \mathrm{~A}$ & 0,1090 \\
\hline Main Effects of Irrigation Factor & 0,0867 & 0,0826 & - \\
\hline \multicolumn{4}{|c|}{ 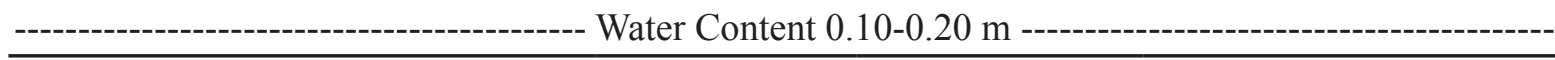 } \\
\hline Sandy Loam & $0,0632 \mathrm{~B}$ & $0,0907 \mathrm{~B}$ & 0,0770 \\
\hline Sandy Clay Loam & $0,1587 \mathrm{~A}$ & $0,1429 \mathrm{~A}$ & 0,1508 \\
\hline Main Effects of Irrigation Factor & 0,1109 & 0,1168 & - \\
\hline \multicolumn{4}{|c|}{ 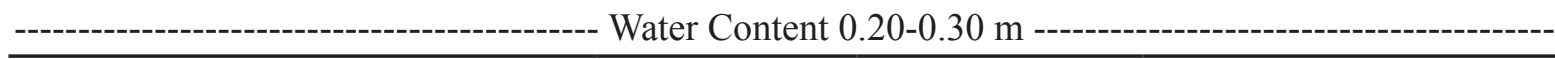 } \\
\hline Sandy Loam & 0,0993 & 0,1065 & $0,1029 \mathrm{~B}$ \\
\hline Sandy Clay Loam & 0,1916 & 0,1852 & $0,1884 \mathrm{~A}$ \\
\hline Main Effects of Irrigation Factor & 0,1455 & 0,1459 & - \\
\hline
\end{tabular}

* Averages not followed by the same capital letter in the column differ by the Tukey test at $5 \%$ probability. 


\section{Conclusions}

The water potential in the peach tree branch can be used in irrigation management and its bether than evaporative demand water replacement.

The water potential in the peach tree branch has a positive relationship with the evaporative demand until the end of the peach harvest and a negative relationship with the soil water storage.

Management of irrigation through the water potential need to be more studied in post-harvest period.

\section{Acknowledgments}

To Embrapa Clima Temperado for the availability of infrastructure to carry out the work; to FAPERGS/ CAPES for granting the scholarship; and peach producer Marcos Fiss for the availability of the area for the accomplishment of the work.

\section{References}

ABRISQUETA, I.; CONEJERO, W.; VALDÉS-VELA, M.; VERA, J.; ORTUÑO, M.F.; RUIZ-SÁNCHEZ, M.C. Stem water potential estimation of drip-irrigated earlymaturing peach trees under Mediterranean conditions. Computers and Electronics in Agriculture, New York, v.114, p.7-13, 2015.

ABRISQUETA, J.; VERA, J.; TAPIA, L.M.; ABRISQUETA, J.M.; RUIZ-SÁNCHEZA, M.C. Soil water content criteria for peach trees water stress detection during the postharvest period. Agricultural Water Management, New York, v.104, p.62-67, 2012.

ALLEN, R.G.; PEREIRA, L.S.; RAES, D.; SMITH, M. Crop evapotranspiration. Rome: FAO, 1998. 297p. (Irrigation and Drainage Paper, 56).

BERGONCI, J.I.; BERGAMASCHI, H.; BERLATO, M.A.; SANTOS, A.O. Potencial de água na folha como um indicador de déficit hídrico em milho. Pesquisa Agropecuária Brasileira, Brasília, DF, v.35, n.8, p.15311540, 2000.

BRAMLEY, H.; EHRENBERGER, W.; ZIMMERMANN, U.; PALTA, J.A.; RÜGER, S.; SIDDIQUE, K.H.M. Noninvasive pressure probes magnetically clamped to leaves to monitor the water status of wheat. Plant and Soil, The Hague, v.369, n.1/2, p.257-268, 2013.
CHASTAIN, D.R.; SNIDER, J.L.; COLLINS, G.D.; PERRY, C.D.; WHITAKER, J.; BYRD, S.A.; OOSTERHUIS, D.M.; PORTER, W.M. Irrigation scheduling using predawn leaf water potential improves water productivity in drip-irrigated cotton. Crop Science, Madison, v.56, n.6, p.3185-3195, 2016.

CONEJERO, W.; MELLISHO, C.D.; ORTUÑO, M.F.; GALINDO, A.; PÉREZ-SARMIENTO, F.; TORRECILLAS, A. Establishing maximum daily trunk shrinkage and midday stem water potential reference equations for irrigation scheduling of early maturing peach trees. Irrigation Science, New York, v.29, p.299309, 2011.

CONESA, M.R.; TORRES, R.; DOMINGO, R.; NAVARRO, H.; SOTO, F.; PÉREZ-PASTOR, A. Maximum daily trunk shrinkage and stem water potential reference equations for irrigation scheduling in table grapes. Agricultural Water Management, Amsterdam, v.172, p.51-61, 2016.

CRUZ, C.D. GENES - a software package for analysis in experimental statistics and quantitative genetics. Acta Scientiarum Agronomy, Maringá, v.35, n.3, p.271-276, 2013.

DE LA ROSA, J.M.; DODD, I.C.; DOMINGO, R.; PÉREZ-PASTOR, A. Early morning fluctuations in trunk diameter are highly sensitive to water stress in nectarine trees. Irrigation Science, New York, v.34, n.2, p.117-128, 2016.

EHRENBERGER, W.; RÜGER, S.; RODRÍGUEZDOMÍNGUEZ，C.M.; DÍAZ-ESPEJO, A.; FERNÁNDEZ, J.E.; MORENO, J.; ZIMMERMANN, D.; SUKHORUKOV, V.L.; ZIMMERMANN, U. Leaf patch clamp pressure probe measurements on olive leaves in a nearly turgorless state. Plant Biology, New York, v.14, n.4, p.666-674, 2012.

ESMAEILPOUR, A.; LABEKE, M.C.V.; SAMSON, R.; BOECKX, P.; DAMME, P.V. Variation in biochemical characteristics, water status, stomata features, leaf carbon isotope composition and its relationship to water use efficiency in pistachio (Pistacia vera L.) cultivars under drought stress condition. Scientia Horticulturae, New York, v.211, p.158-166, 2016.

FACHINELLO, J.C.; PASA, M.S.; SCHMTIZ, J.D.; BETEMPS, D.L. Situação e perspectivas da fruticultura de clima temperado no Brasil. Revista Brasileira de Fruticultura, Jaboticabal, v.33, p.109-120, 2011. Número especial 
FULTON, A.; BUCHNER, R.; GRANT, J.; PRICHARD, T.; LAMPINEN, B.; SCHWANKL, L.; SHACKEL, $K$. Irrigation schedulin using stem water potential (SWP) measurements. Davis: Fruit \& Nutrition Research \& Information, 2007. Disponível em: <http:// informatics.plantsciences.ucdavis.edu/Brooke_Jacobs/ datainterpretation.html\#>. Acesso em: 07 jul. 2015.

GONZALEZ-DUGO, V.; ZARCO-TEJADA, P.; BERNI, J.A.J.; SUÁREZ, L.; GOLDHAMER, D.; FERERES, E. Almond tree canopy temperature reveals intra-crown variability that is water stress-dependent. Agricultural and Forest Meteorology, Amsterdam, v.154, p.156-165, 2012.

HOCHBERG, U.; HERRERA, J.C.; DEGU, A.; LAZAROVITCH, N. Evaporative demand determines the relative transpirational sensitivity of deficit-irrigated grapevines. Irrigation Science, v.35, n.1, p.1-9, 2017. Disponível em: <htpp://doi.org/urn:doi: 10.1007/s00271016-0518-4>.

IBGE - Instituto Brasileiro de Geografia e Estatística. Produção Agrícola Municipal. Pêssego. Brasília, DF: Ministério do Planejamento, Orçamento e Gestão, 2017.

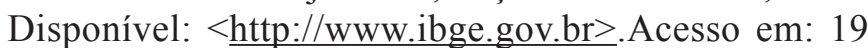
jan. 2017.

ITIER, B.; FLURA, D.; BELABBES, K.; KOSUTH, P.; RANA, G.; FIGUEIREDO, L. Relations between relative evapotranspiration and predawn leaf water potential in soyabean grown in several locations. Irrigation Science, Berlin, v.13, p.109-114, 1992.

MADAIL, J.C.M. O cultivo do pessegueiro no Rio Grande do Sul.In: RASEIRA, M.C.B.; PEREIRA, J.F.M.; CARVALHO, F.L.C. Pessegueiro. Brasília, DF: Embrapa, 2014. p.615-624.

MARCHAND, G.; MAYJONADE, B.; VARES, D.; BLANCHET, N.; BONIFACE, M.C.; MAURY, P.; ANDRIANASOLO, F.N.; BURGER, P.; DEBAEKE, P.; CASADEBAIG, P.; VINCOURT, P.; LANGLADE, N.B. A biomarker based on gene expression indicates plant water status in controlled and natural environments. Plant, Cell \& Environment, Oxford, v.36, n.12, p.2175-2189, 2013.

MARSAL, J.; CASADESUS, J.; LOPEZ, G.; MATA, M.BELLVERT, B.; GIRONA, J. Sustainability of regulated deficit irrigation in a mid-maturing peach cultivar. Irrigation Science, New York, v.34, p.201-208, 2016.
MCCTCHAN, H.; SHACKEL, K.A. Stem-water potential as a sensitive indicator of water stress in prune trees (Prunus domestica L.cv.French). Journal of the American Society for Horticultural Science, Alexandria, v.117, n.4, p.607-611, 1992.

MEDRANO, H.; TOMÁS, M.; MARTORELL, S.; FLEXAS, J.; HERNÁNDEZ, E.; ROSSELLÓ, J.; POU, A.; ESCALONA, J.M.; BOTA, J. From leaf to wholeplant water use efficiency (WUE) in complex canopies: limitations of leaf WUE as a selection target. The Crop Journal, Amsterdam, v.3, n.3, p.220-228, 2015.

MIRÁS-AVALOS, J.M; PÉREZ-SARMIENTO, F.; ALCOBENDAS, R.; ALARCÓN, J.J.; MOUNZER, O.; NICOLÁS, N. Using midday stem water potential for scheduling déficit irrigation in mid-late maturing peach trees under Mediterranean conditions. Irrigation Science, New York, v.34, p.161-173, 2016.

MONTEIRO, A.B.; ROMANO, L.R.; REISSER JUNIOR, C.; TERRA, V.S.S.; TIMM, L.C. Calibration of a capacitance water contente probe in na aquertic hapludalf soil. . In. ENCONTRO BRASILEIRO DE FISICA DO SOLO, 3., 2015. Curitiba. Anais...

REMORINI, D.; MASSAI, R. Comparison of water status indicators for young peach trees. Irrigation Science, New York, v.22, n.1, p.39-46, 2003.

RODRIGUEZ-DOMINGUEZ, C.M.; EHRENBERGER, W.; SANN, C.; RÜGER, S.; SUKHORUKOV, V.; MARTÍN-PALOMO, M.J.; DIAZ-ESPEJO, A.; CUEVAS, M.V.; TORRES-RUIZ, J.M.; PEREZ-MARTIN, A.; ZIMMERMANN, U.; FERNÁNDEZ, J.E. Concomitant measurements of stem sap flow and leaf turgor pressure in olive trees using the leaf patch clamp pressure probe. Agricultural Water Management Amsterdam, v.114, p.50-58, 2012.

SANTOS, H.G. dos; JACOMINE, P.K.T.; ANJOS, L.H.C. dos; OLIVEIRA, V.A. de; OLIVEIRA, J.B. de; COELHO, M.R.; LUMBRERAS, J.F.; CUNHA, T.J.F. (Ed.). Sistema brasileiro de classificação de solo. 2.ed. Rio de Janeiro: Embrapa Solos, 2006. 306 p.

S C H O L A N D E R, P.; B R A D S T REE T, E.D.; HEMMINGSEN, E.A.; HAMMEL, H.T. Sap pressure in vascular plants: Negative hydrostatic pressure can be measured in plants. Science, New York, v.148, n.3668, p.339-346, 1965.

SILVA, M.A.S. da; MAFRA, Á.L.; ALBUQUERQUE, J.A.; BAYER, C.; MIELNICZUK, J. Atributos físicos do solo relacionados ao armazenamento de água em um Argissolo Vermelho sob diferentes sistemas de preparo. Ciência Rural, Santa Maria, v.35, n.3, p.544-552, 2005. 
SIMÕES, F. Padrões de resposta do pessegueiro cv.Maciel a diferentes níveis de déficit hídrico. 2007. Dissertação (Mestrado em Agronomia) - Universidade Federal de Pelotas, Pelotas, 2007.

TERRA, V.S.S. Variabilidade espacial e temporal de atributos agronômicos em pomar de pessegueiro. 2012. Tese (Doutorado em Sistemas de Produção Agrícola Familiar) - Universidade Federal de Pelotas, Pelotas, 2012.

TORRES-RUIZ, J.M.; DIAZ-ESPEJO, A.; MORALESSILLERO, A.; MARTIIN-PALOMO, M.J.; MAYR, S.; BEIKIRCHER, B.; FERNÁNDEZ, J.E. Shoot hydraulic characteristics, plant water status and stomatal response in olive trees under different soil water conditions. Plant and Soil, The Hague, v.373, n.1-2, p.77-87, 2013.

VALANCOGNE, C.; AMÉGLIO, T.; FERREIRA, I.; COHEN M.; ARCHER, P.; DAYAU, S.; DAUDET, F.A. Relations between relative transpiration and predawn leaf water potential in different fruit trees species. Acta Horticulturae, The Hague, v.449, n.2, p.423-430, 1996.

WELLS, L. Irrigation water management for Pecans in humid climates. Hortscience, Alexandria, v.50, n.7, p.1070-1074, 2015.
ZARCO-TEJADA, P.J.; GONZÁLEZ-DUGO, V.; BERNI, J.A.J. Fluorescence, temperature and narrowband indices acquired from a UAV platform for water stress detection using a micro-hyperspectral imager and a thermal camera. Remote Sensing of Environment, New York, v.117, p.322-337, 2012.

ZIMMERMANN, U.; RÜGER, S.; SHAPIRA, O.; WESTHOFF, M.; WEGNWE, L.H.; REUSS, R.; GESSNER, P.; ZIMMERMANN, G.; ISRAELI, Y.; ZHOU, A.; SCHWARTZ, A.; BAMBERG, E.; ZIMMERMANN, D. Effects of environmental parameters and irrigation on the turgor pressure of banana plants measured using the non-invasive, online monitoring leaf patch clamp pressure probe. Plant Biology, Stuttgart, v.12, n.3, p.424-436, 2010. 